\title{
TRI OUT UJIAN NASIONAL DAN PEMBAHASANYA PADA SOAL MATEMATIKA SISWA KELAS IX MTS DAARUSY SYIFAA TIRTANADI LOMBOK TIMUR
}

\author{
Mahsup' ${ }^{1}$ Abdillah'2, Vera Mandailina ${ }^{3}$ \\ 1,2,3 Pendidikan Matematika, Universitas Muhammadiyah Mataram, Indonesia \\ supyeka@gmail.com ${ }^{1}$, ahmad fawwaz18@yahoo.com²,vrmandailina@gmail.com ${ }^{3}$
}

\begin{abstract}
ABSTRAK
Abstrak: Solusi yang ditawarkan dalam kegiatan triout yaitu kegiatan triout dapat sebagai latihan atau ujicoba mengerjakan soal khususnya pada soal matematika sehingga dapat memudahkan siswa dalam menjawab soal ujian nasional dan siswa dapat memahami trik menjawab soal secara cepat dengan proses yang singkat. Metode pelaksanaan kegiatan pengabdian terdiri dari persiapan, perencanaan dan pelaksanaan. Hasil kegiatan tri out sangat bermanfaat untuk meningkatkan pemahaman siswa terhadap materi yang akan diujikan pada ujian nasional selain itu dapat mendorong siswa supaya lebih giat belajar dan berlatih dalam mengerjakan soal matematika atau soal prediksi pada ujian nasional serta dapat menambah informasi dan tambahan materi khususnya pada materi matematika.
\end{abstract}

Kata Kunci: Try Out UN

\begin{abstract}
The solution offered in the triout activity is triout activities can be as an exercise or a test to work on mathematical questions so that they can help students in answering national exam questions and students can discuss quick answer questions with a quick process. Method The implementation of service activities consists of preparation, planning and implementation. The results of the outer tri activity are very useful for increasing students' understanding of the material to be tested on national examinations but can encourage students to study hard and work on math questions or prediction questions on national examinations to provide additional information and material on mathematical material.
\end{abstract}

Keywords: Try Out of UN

\section{A. LATAR BELAKANG}

Pelaksanaan ujian nasional dinilai tidak dapat menjadi penentu kualitas hasil belajar siswa selama menempuh pendidikan di sekolah. Sayangnya, pemerintah justru menjadikan ujian nasional sebagai alat ukur keberhasilan pendidikan. Ada banyak cara mengukur prestasi belajar, ujian nasional bukan satu-satunya. Menurut Abduhzen (2013) menyatakan sebelum memberikan ujian nasional, seharusnya pemerintah dapat memperhitungkan manfaat pelaksanaan ujian tersebut. Perhitungan manfaat itu, dapat berangkat dari tiga asusmi yaitu teoritis pedagogis, legalitas formal dan asumsi pragmatis. Sejauh mana kegunaannya dan bias dipertanggungjawabkan. Sejauh mana implikasi positif maupun negatifnya.

Ada beberapa hal yang dapat dilakukan pemerintah untuk mengganti ujian nasional sebagai bahan evaluasi siswa. Pertama, pemerintah harus kembali kepada undang-undang evaluasi hasil belajar siswa yang dilakukan pendidik. Di setiap sekolah, seorang guru seharusnya dapat 
mengevaluasi dan melakukan ujian perbaikan (remedial) hingga siswa lulus dari mata pelajaran yang diujikan. Kedua, pemerintah harus memastikan agar setiap guru dapat bekerja sesuai arah dan pedoman yang ditetapkan dalam standar kompetensi kelulusan. Sehingga, ketika seorang siswa mengikuti ujian, guru dapat meluluskan jika siswa tersebut telah memenuhi standar kompetensi yang ditentukan. Kemudian, untuk pengukuran dan pemetaan kualitas secara nasional, BSNP (Badan Standar Nasional Pendidikan) dapat melakukan ujian nasional secara berkala lima tahun sekali.

Dalam menghadapi ujian nasional umumnya siswa dipedesaan tidak terlalu diperhatikan apalagi melakukan persiapan secara maksimal. Siswa dipedesaan lebih banyak menghabiskan waktunya untuk bermain atau pergi kesawah untuk membatu orang tua. Disamping itu perhatian para orang tua terhadap pendidikan anak-anaknya masih sangat kurang, hal ini disebabkan karena latarbelakang pendidikan para orang tua yang rata-rata tamatan SD sampai dengan SMA sehingga pendidikan anak tidak dapat diarahkan dengan baik.

Dalam menghadapi ujian nasional diharapkan siswa lebih banyak belajar, baik secara kelompok maupun dalam bimbingan belajar. Salah satu usaha yang harus dilakukan oleh siswa yaitu berlatih mengerjakan soal ujian melalui kegiatan tri out. Tri out merupakan usaha untuk melakukan uji coba atau berlatih dalam mengerjakan soal ujian nasional khususnya pada soal matematika. Dalam pelaksanaan triout siswa mengerjakan soal dengan teknik menjawab yang cepat dan mengetahui metode yang tepat sesuai dengan rumus dalam menjawab soal tersebut.

Solusi yang ditawarkan setelah mengikuti kegiatan tri out sebagai berikut :

1. Kegiatan triout sebagai latihan atau ujicoba mengerjakan soal khususnya pada soal matematika sehingga dapat memudahkan siswa dalam menjawab soal ujian nasional.

2. Dalam kegiatan tri out siswa dapat memahami trik menjawab soal secara cepat dengan proses yang singkat.

Dari kegiatan pengabdian masyarakat diharapakan dapat memberikan manfaat sebagai berikut:

1. Manfaat teoritis yaitu dengan kegiatan triout bagi siswa dapat menambah pemahaman dalam mengerjakan soal matematika dan mengetahui cara menjawab soal dengan singkat.

2. Manfaat praktis yaitu kegiatan tri uot sebagai ujicoba atau latihan dalam menghadapi ujian nasional

\section{B. METODE PELAKSANAAN}

Metode pelaksanaan kegiatan pengabdian melalui beberapa tahapan yaitu kegiatan persiapan ini dimulai dengan kegiatan observasi untuk mengetahui kondisi di sekolah berkaitan dengan kegiatan pelatihan dan bagiamana sistematika tri out yang dilakukan di sekolah. Kegiatan persiapan ini juga dilakukan dengan kegiatan wawancara terhadap pihak sekolah.

Berdasarkan hasil observasi dan wawancara tersebut, tim pengabdian melakukan diskusi internal dan mengkaji literatur guna membahas solusi yang dapat digunakan untuk membantu permasalahan yang ada di sekolah 
tersebut berkenaan dengan kegiatan tri out. Selain itu tim pengabdian melakukan diskusi dengan mahasiswa KKN dalam penyusunan jadwal kegiatan yang akan dilakukan selama kegiatan pelatihan.

Dalam kegiatan perencanaan tim pengabdian mempersiapkan alat dan bahan dalam kegiatan tri out dan membagi tugas dengan tim pengabdian. Kegiatan pelaksanaan pengabdian dengan menerapkan langkah-langkah dalam pelaksanaan tri out dan pendampingan serta berdiskusi dalam dalam menemukan jawaban pada soal tersebut. Pelaksanaan kegiatan pengabdian dilaksanakan selama 3 hari yang dirangkaikan dengan realisasi Program Mahasiswa KKN dan tempat kegiatan dilakukan di aula kantor desa Tirtanadi. Sasaran kegiatan triout adalah siswa kelas IX dengan jumlah antara 20 sampai dengan 30 siswa MTs Daarusy Syifaa yang berada di desa Tirtanadi.

\section{HASIL DAN PEMBAHASAN}

\section{Pelaksanaan Kegiatan}

Kegitan tri out dilaksanakan selama 3 hari. Sebelum ke lokasi pengabdian terlebih dahulu tim membuat soal triout sebanyak 20 soal. Tingkat kesulitan soal yang dibuat disesuaikan dan bervariasi. Soal yang buat beragam sesuai dengan kisi-kisi soal pada ujian nasional yang telah ditetapkan oleh kemdiknas. Kemudian pada hari Kamis tanggal 20 Maret 2014 kegitan triout mulai dilaksanakan.

Kegiatan pertama yaitu kegiatan triout yang dilaksanakan pada pukul 09.00 sampai dengan pukul 10.30 Wita siswa mengerjakan soal Triout dengan jumlah soal 20 butir. Tempat duduk siswa diatur dengan rapi dan siswa duduk sendiri dalam satu meja. Selama mengerjakan triout siswa diawasi oleh tim pengabdian agar tidak bisa kerjasama dengan teman sebangku atau teman disamping kiri dan kanan. Siswa mengerjakan soal dengan tenang dan dalam kondisi yang kondusif sampai berakhirnya waktu yang telah ditentukan. Setelah waktu berakhir siswa mengumpulkan lembar jawaban dan langsung pulang dari sekolah.

Kegiatan yang dilaksanakan pada pertemuan kedua adalah membahas soal yang telah diujikan pada pertemuan pertama. Pembahasan soal dimulai dengan menanyakan kepada siswa tentang soal yang dirasakan sulit dalam mengerjakannya. Ada siswa yang menjawab soal nomor 3 tentang perkalian matrik dan operasinya dan ada juga siswa yang kesulitan pada soal yang nomor 5 tentang sistem persamaan linear dua variabel. Kemudian tim pengabdian menjelaskan cara melakukan operasi perkalian pada matrik dan cara menentukan penyelesaian sistem persamaan linear dua variable dengan menggunakan metode grafik, eliminasi dan substitusi. Kemudian tim mendiskusikan serta membimbing siswa dalam menjawaban soal triout pada soal yang lain.

\section{Kontribusi Mitra}

Kegiatan triout memberikan kontribusi baik bagi siswa dan sekolah. Adapun Kontribusi bagi siswa yaitu:

a. Dapat sebagai ujicoba dalam mengerjakan soal ujian nasional 
b. Untuk mengetahui tingkat pemahaman siswa terhadap materi yang akan diujikan pada ujian nasional

c. Dapat meningkatkan pemahaman terhadap materi yang akan diujikan pada ujian nasional

d. Memperoleh informasi atau trik-trik dalam menjawab soal dengan cara singkat.

Sedangkan kotribusi bagi sekolah yaitu:

a. Sekolah terbantu dalam mensukseskan siswa untuk lulus dalam menghadapi ujian nasional.

b. Dengan kegiatan triout sekolah mendapatkan informasi tambahan dari tim pengabdian.

c. Dengan kegiatan triout membuat siswa termotivasi untuk lebih giat belajar.

\section{Potret Permasalahan Mitra}

Kegiatan triout bagi siswa kelas IX harus lebih sering dilakukan. Di MTs Daarusy Syifaa desa Tirtanadi kegiatan triout sudah sering dilakukan untuk mempersiapkan anak didik dalam menempuh ujian nasional. Ada beberapa permasalahan yang dihadapi di MTs Daarusy Syifaa desa Tirtanadi yaitu kurangnya motivasi siswa dalam belajar dan fasilitas berupa buku paket atau buku prediksi soal ujian nasional. Disamping itu masih rendahnya dukungan orang tua dan masyarakat dalam mengarahkan putra putrinya untuk lebih giat belajar dalam menghadapi ujian nasional. Penduduk desa Tirtanadi mayoritas sebagai petani sehingga pengawasan terhadap putra-putrinya masih kurang.

\section{SIMPULAN DAN SARAN}

Dari kegiatan pengabdian kepada masyarakat berupa kegiatan triout pada siswa kelas IX MTs Daarusy Syifaa desa Tirtanadi disimpulkan sebagai berikut:

1. Kegiatan triout pada soal matematika dan pembahasannya sangat bermanfaat untuk meningkatkan pemahaman siswa terhadap materi yang akan diujikan pada ujian nasional.

2. Kegiatan triout dapat mendorong siswa supaya lebih giat belajar dan berlatih dalam mengerjakan soal matematika atau soal prediksi pada ujian nasional.

3. Dengan kegiatan triout dapat menambah informasi dan tambahan materi khususnya pada materi matematika.

Dalam menghadapi ujian nasional diharapkan para siswa lebih aktif dalam berdiskusi atau bekerja kelompok untuk mendiskusikan permasalah yang akan diujikan pada ujian nasional. Siswa juga lebih banyak belajar dan para orang tua membantu, mengawasi dan mendorong putra-putrinya untuk lebih semangat belajar.

\section{UCAPAN TERIMA KASIH}

Tim Abdimas mengucapkan terima kasih kepada Lembaga Pengabdian Pada Masyarakat (LPPM) Universitas Muhammadiyah Mataram yang telah mendukung kegiatan pengabdian ini sehingga terlaksana dengan baik. Selanjutnya, tim Abdimas mengucapkan terima kasih kepada siswa MTs 
Daarusy Syifaa Desa Tirtanadi yang telah bersedia mengikuti kegiatan ini dengan semangat.

\section{DAFTAR RUJUKAN}

[1] Billy Suandito. (2018). Persiapan Siswa Kelas VI Menghadapi Ujian Sekolah Tingkat SD. Jurnal Abdimas Musi Charitas, 2(1), h. 22-26

[2] Dina Merris Maya Sari. (2018). Persiapan UNAS SD Melalui Pelaksanaan Dan Pembahasan Try Out Di Desa Sumokali. Jurnal Padi, 1(1), h. 11-15

[3] Ellisia Kumalasari, dkk. (2017). Aplikasi Tryout Ujian Online untuk SMA/SMK Sederajat. Jurnal Edukasi, 4(3), h. 1-5

[4] Habibi Ratu Perwira Negara, Farah Heniati Santosa, Samsul Bahri. (2017). Peningkatan Kompetensi ICT Guna Simulasi UNBK Siswa MTs Nurul Ihsan Kecamatan Jonggat Kabupaten Lombok Tengah. Jurnal masyarakat Mandiri, 1(1), 1-9

[5] LPPM. (2016). Buku Pedoman Pengabdian Kepada Masyarakat. Mataram : UMMat

[6] Rio Wirawan, M. Bayu Wibisono. (2018). IBM Siswa yang Menghadapi Ujian Nasional Berbasis Komputer (UNBK). Jurnal Mediteg, 3(1), h. 1-5 